\title{
Assessment of Groundwater Quality for Domestic and Irrigation Purposes in Northern Bamenda (Cameroon)
}

\author{
Alice Magha1*, Margaret Tita Awah², Gus Djibril Kouankap Nono', Primus Azinwi Tamfuh 3,4, \\ Pierre Wotchoko1, Mercy Adoh', Veronique Beyala Kamgang Kabeyene ${ }^{5}$ \\ ${ }^{1}$ Department of Geology, Higher Teacher Training College, University of Bamenda, Bambili, Cameroon \\ ${ }^{2}$ Department of Biology, Higher Teacher Training College, University of Bamenda, Bambili, Cameroon \\ ${ }^{3}$ Department of Soil Science, Faculty of Agronomy and Agricultural Sciences, University of Dschang, Dschang, Cameroon \\ ${ }^{4}$ Department of Mining and Mineral Engineering, National Higher Polytechnic Institute, University of Bamenda, Bambili, Cameroon \\ ${ }^{5}$ Department of Earth Sciences, Higher Teacher Training College, University of Ngaoundere, Bertoua, Cameroon \\ Email: *amufur@yahoo.com
}

How to cite this paper: Magha, A., Awah, M.T., Nono, G.D.K., Tamfuh, P.A., Wotchoko, P., Adoh, M. and Kabeyene, V.B.K. (2021) Assessment of Groundwater Quality for Domestic and Irrigation Purposes in Northern Bamenda (Cameroon). Journal of Water Resource and Protection, 13, 1-19.

https://doi.org/10.4236/jwarp.2021.131001

Received: October 22, 2020

Accepted: January 17, 2021

Published: January 20, 2021

Copyright $\odot 2021$ by author(s) and Scientific Research Publishing Inc. This work is licensed under the Creative Commons Attribution International License (CC BY 4.0).

http://creativecommons.org/licenses/by/4.0/

\section{(c) (i) Open Access}

\begin{abstract}
Safe and reliable drinking water availability constitutes a nightmare in many towns of developing countries and is usually appreciated from its physical appearance without prior knowledge of its chemical and biological properties. This study investigates the suitability of groundwater for domestic and irrigational purposes through physico-chemical and bacteriological analyses in the Northern part of Bamenda Town (Cameroon). Thus, 20 groundwater samples were collected from hand-dug wells and spring sources in September 2018 (rainy season) and February 2019 (dry season) and physico-chemical and bacteriological characteristics were determined. The results revealed that $\mathrm{pH}$ ranged from 5.5 to 6.6 , thus enabling the classification of the water as slightly acidic. Electrical conductivity varied between $0.01-0.06 \mu \mathrm{S} / \mathrm{cm}$. The relative abundance of ions was such that $\mathrm{Ca}^{2+}>\mathrm{K}^{+}>\mathrm{Mg}^{2+}>\mathrm{Na}^{+}$for cations and $\mathrm{HCO}_{3}^{-}>\mathrm{Cl}^{-}>\mathrm{NO}_{3}^{-}>\mathrm{SO}_{4}^{-}$for anions. The water types were Ca$\mathrm{Mg}-\mathrm{NO}_{3}$ in both dry and rainy seasons. The results revealed that the mechanisms controlling groundwater chemistry are rock weathering and atmospheric precipitation. Indicator bacteria such as E. coli, Shigella, Enterobacteria, Vibrio, Streptococcus and Staphylococcus were detected in the studied groundwater samples, thus the water sources may pose a threat to public health.
\end{abstract}

\section{Keywords}

Reliable Drinking Water, Groundwater Quality, Spring Sources, Chemical 


\section{Introduction}

The well-being of humans in any community requires substantial quantities of potable water for domestic, agricultural and industrial purposes [1] [2] [3]. Water is a natural resource that is at the centre of sustainable development and is critical for socio-economic development and healthy ecosystems [4] [5]. It is a universal solvent and would dissolve almost all organic and inorganic solids and gases it comes in contact with, making the existence of pure water in nature very rare. Even though about $2 / 3$ of the land surface of the Earth is occupied by water, many communities lack ample quantities for daily activities [6]. A greater proportion of this underprivileged population lives in developing countries of Africa, South America, India and South East Asia. Studies have shown that unsafe water associated with low sanitation and hygiene represents the leading cause of death in these countries, and it is estimated that about 1.6 million people die every year from water-related diseases, $90 \%$ constituting children below five years of age [7]. Water in surface reservoirs is vulnerable to contaminants from diverse sources and is being degraded tremendously. In order to cope with the demand for water for various activities, many communities rely solely on groundwater resources [3]. Groundwater is used by about 2 billion people worldwide making it the single most used natural resource [8]. Globally, groundwater provides $25 \%$ - $40 \%$ of the world's drinking water [9]. Despite its importance, groundwater is poorly understood and often undervalued and groundwater aquifers can become depleted when extraction rates exceed replenishment [10]. When it becomes polluted or contaminated, unlike surface water, the ability to purify itself is limited and usually, it is very expensive to restore polluted groundwater [11]. The quality of groundwater can be greatly affected by natural factors [12] as well as anthropogenic factors such as sewage leakages, oil spillage, combustion, application of pesticides and fertilizers, house chemicals, littering and many others [13].

In Africa safe drinking water is a major challenge as studies indicate that about 300 million people lack access to safe drinking water, many of whom are among the poor [7]. The United Nations Convention on the rights of the child further stipulates that their partners have the obligation to provide clean drinking water to all children [14]. In Sub-Saharan Africa, $42 \%$ of the population lacks improved water and sanitation. This therefore, leads to about 1.8 million deaths annually from diarrheal diseases with $90 \%$ being children under the age of 5 [15]. Environmental pollution is unavoidable, thus careful characterization of the resource is required to guide investment in water supply and to manage the resource to minimize environmental degradation and widespread depletion [16].

In Cameroon, access rate to drinking water hardly attains 32\% [17] despite the fact that Cameroon is the second country in Africa after the Democratic Repub- 
lic of Congo in terms of quantity of available water resources that is estimated at 322 billion meters cube [18]. However, these water resources are not evenly distributed due to variations in the topography, rainfall pattern and climatic changes. Conversely, these water sources are poorly harnessed resulting in acute shortage of pipe borne water supply in many localities in the country.

In order to cope with the water challenges, many residents turn to abstract drinking water from any obtainable sources that include groundwater from springs, wells and boreholes that are not protected and are therefore vulnerable to contamination from anthropogenic influences. Hence, it is absolutely necessary to regularly monitor the quality of these water sources in order to guarantee the health of the residents as well as the ecosystem.

Many petrographical research works have been carried out in the study area [19] [20] [21] [22], microbial pollution of surface water [23] [24], landslide study [25] and flood management [26]. This study therefore, seeks to assess the quality of groundwater in Northern Bamenda, to determine its fitness for domestic and irrigational purposes and also investigate the mechanisms that control groundwater chemistry.

\section{Geographical and Geological Setting of the Study Area}

Geographically, the study area is found in Bamenda, the Regional Headquarter of the North West Region of Cameroon and constitutes part of the Cameroon Volcanic Line. It extends from latitudes $5^{\circ} 56^{\prime \prime} \mathrm{N}$ to $5^{\circ} 58^{\prime \prime} \mathrm{N}$ of the Equator and from longitude $10^{\circ} 09^{\prime \prime} \mathrm{E}$ to $10^{\circ} 11^{\prime \prime} \mathrm{E}$ of the Greenwich Meridian (Figure 1) and lies at an altitude of about $1200 \mathrm{~m}$ above sea level. It is characterised by steep slopes, which influence the drainage of the area [27], with a surface area of about $173 \mathrm{~km}^{2}$ [28]. The climate is the Cameroonian type equatorial climate, characterized by two seasons: a rainy season of about 7 months, from April to October and a dry season of about 5 months from November to March. The mean annual rainfall is $2670 \mathrm{~mm}$ and the average annual temperature is $25^{\circ} \mathrm{C}$. The area is drained by River Mezam and its tributaries which flow from the Bamenda escarpment, passing through the city center exhibiting a dendritic pattern. The vegetation is typically grassland savannah and has been greatly modified in many areas by the planting of secondary eucalyptus forest [29].

Geologically, Bamenda is one of the most important volcanic provinces of the continental sector of the Cameroon Volcanic Line (CVL) and lies between the Bamboutos Mountains in the southwest and the Oku Massif in the northeast. The Bamenda Highlands constitute the fourth largest massif in the continental segment of the CVL [21]. This volcanic province is made up of mafic and felsic Cenozoic massifs emplaced on a Pan African basement [19]. These massifs consist of basanites, hawaiites, mugearites, ignimbrite, trachytes and rhyolites which are Tertiary in age [30] [31] [32] and granito-gneissic basement of Pan-African age [33]. 


\section{Materials and Methods of Study}

\subsection{Data Collection}

Twenty groundwater samples were collected from 2 springs and 3 wells (Figure 1) during the wet and dry seasons to investigate the potability of the water sources. The water samples were collected in 1 litre containers which were rinsed 3 times in the field with distilled water and the water samples to be collected. At each sampling point, two separate water samples were collected, one for physico-chemical analyses and the other for bacteriological analyses. The sampling points and their codes are presented in Table 1.

\subsubsection{Physical Characteristics}

Physical parameters of the water samples such as temperature, $\mathrm{pH}$, turbidity and electrical conductivity were measured in the field using a multiparameter probe.

\subsubsection{Chemical Characteristics}

Chemical parameters of the water samples were analysed in the laboratory of Soil and Environmental Chemistry of the University of Dschang, Cameroon. The water samples were stored at $4^{\circ} \mathrm{C}$. Major anions $\left(\mathrm{Cl}^{-}, \mathrm{NO}_{3}^{-}\right.$, and $\mathrm{SO}_{4}^{2-}$, and

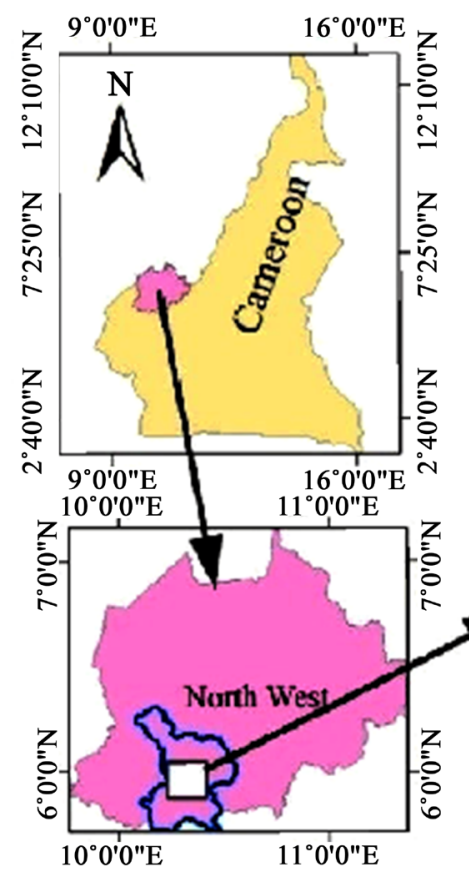

Legend

- Localities

Roads

National

- Regional $\square$ Study area

...-Rural
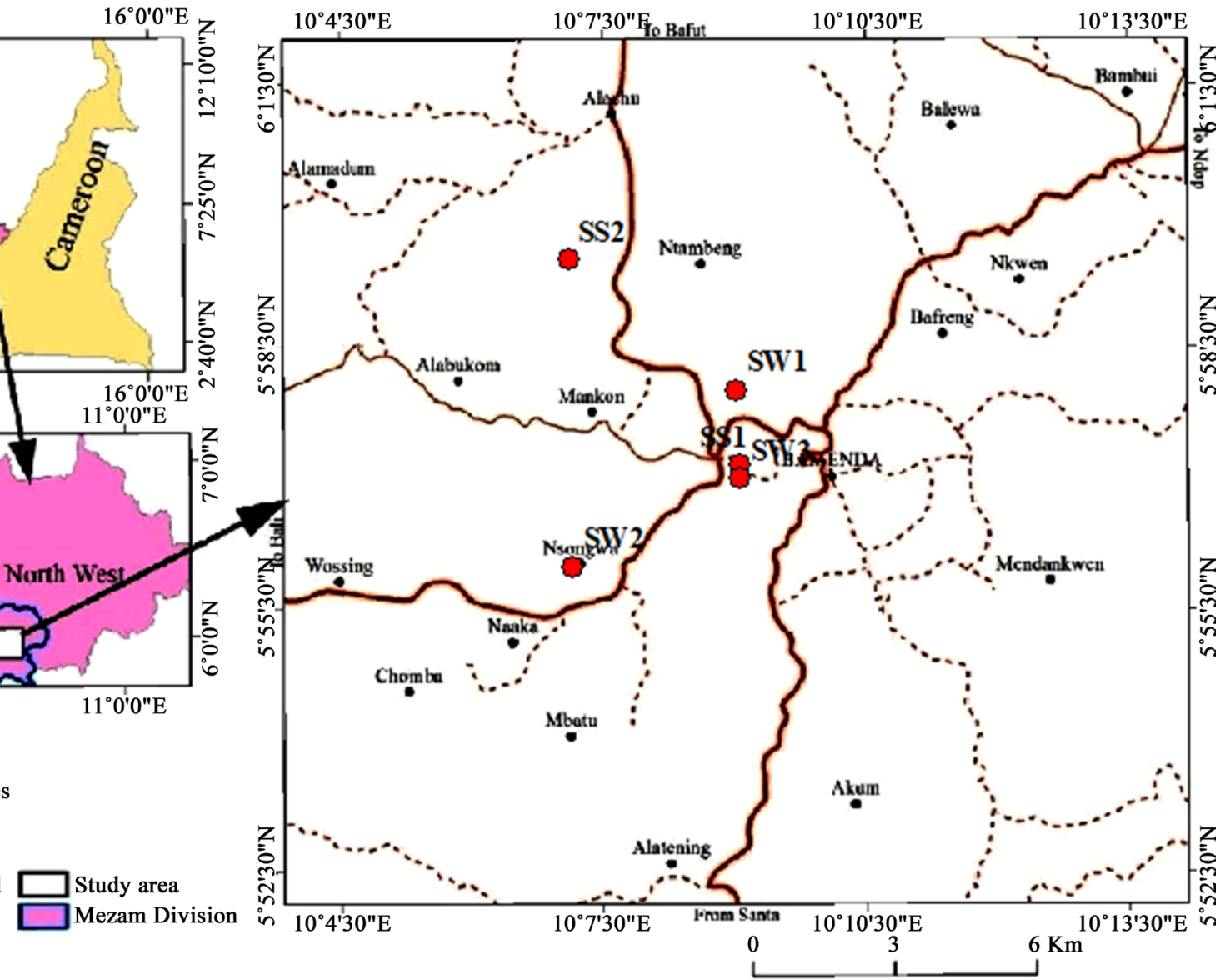

Figure 1. Location map of the study area with Positions of Groundwater Sampling Points: SS1, SS2, SW1, SW2 and SW3 are spring and well sampling points. 
Table 1. Coordinates and location of spring and well sampling points in study area.

\begin{tabular}{|c|c|c|c|}
\hline Sampling point & Sample codes & Coordinates & Elevation \\
\hline Parcours Vita (spring) & SS1 & $\begin{array}{l}\text { N05 } 57.962^{\prime} \\
\text { E } 010^{\circ} 09.342^{\prime}\end{array}$ & $1227 \mathrm{~m}$ \\
\hline Small Mankon (Hand-dug well) & SW1 & $\begin{array}{l}\mathrm{N} 05^{\circ} 58.116^{\prime} \\
\text { E } 010^{\circ} 09.010^{\prime}\end{array}$ & $1229 \mathrm{~m}$ \\
\hline Mile Seven (spring) & SS2 & $\begin{array}{l}\text { N } 05^{\circ} 59.300^{\prime} \\
\text { E } 010^{\circ} 07.597^{\prime}\end{array}$ & $1230 \mathrm{~m}$ \\
\hline Mbatu (Hand-dug well) & SW2 & $\begin{array}{l}\mathrm{N} 05^{\circ} 56.000^{\prime} \\
\text { E } 010^{\circ} 07.911^{\prime}\end{array}$ & $1243 \mathrm{~m}$ \\
\hline Big Mankon (Hand-dug well) & SW3 & $\begin{array}{l}\text { N } 05^{\circ} 57.006^{\prime} \\
\text { E } 010^{\circ} 09.314^{\prime}\end{array}$ & $1270 \mathrm{~m}$ \\
\hline
\end{tabular}

cations $\left(\mathrm{Na}^{+}, \mathrm{K}^{+}, \mathrm{Ca}^{2+}, \mathrm{Mg}^{2+}\right.$ and $\left.\mathrm{Fe}^{2+}\right)$ were analyzed by the ion chromatography (IC, Metrohm-881-Compact). Carbonate $\left(\mathrm{CO}_{3}^{2-}\right)$, bicarbonate $\left(\mathrm{HCO}_{3}^{-}\right)$and chloride $\left(\mathrm{Cl}^{-}\right)$ions were analyzed by volumetric titration method. Sulphate $\left(\mathrm{SO}_{4}^{2-}\right)$, nitrate $\left(\mathrm{NO}_{3}^{-}\right)$and phosphate $\left(\mathrm{PO}_{4}^{3-}\right)$ ions were determined by spectrophotometric technique according to the methods described by the American Public Health Association [34].

Sodium adsorption ratio (SAR) of the studied groundwater samples was gotten from the equation below.

$$
\mathrm{SAR}=\mathrm{Na}^{+} / \sqrt{1 / 2}\left(\mathrm{Ca}^{2+}+\mathrm{Mg}^{2+}\right)
$$

\subsubsection{Bacteriological Analysis}

Escherichia coli and faecal coliforms were determined using the membrane filtration procedure. Here, $1 \mathrm{ml}$ of water sample was added to $9 \mathrm{ml}$ of distilled water. Each sample was diluted three times. A membrane was placed on a sterilized Wheaton Filtration funnel used to filter $20 \mathrm{ml}$ of undiluted sample. The funnel was sterilized after each filtration to avoid interferences. Several diluted samples were then processed so as to get filter plates with appropriate range of colonies. These filter plates were placed in an incubator at different temperature conditions for different bacteria. These were: $44^{\circ} \mathrm{C}$ for $E$. coli and faecal coliform, $35^{\circ} \mathrm{C}$ for Streptococcus and total coliform. The results are presented as CFU/100ml.

\section{Results and Discussion}

\subsection{Physical Parameters}

The physical and chemical characteristics of the studied groundwater are presented in Table 2. $\mathrm{pH}$ values ranged from 5.5 to 6.6, with a mean of 6.05 in the wet season while in the dry season, $\mathrm{pH}$ values varied from 5.9 to 6.3 with an average of 6.10. The highest value (6.6) was recorded at WS2 and the lowest at WS3 (5.5) all in the wet season (Figure 2(a)). The acidic $\mathrm{pH}$ of the studied groundwater samples placed $90 \%$ of the water samples slightly below the WHO [35] permissible limit of $6.5-8.5$ except for samples SS2 and WS2. Slightly to 
Table 2. Summary of physical and chemical parameters in the wet and dry seasons.

\begin{tabular}{|c|c|c|c|c|c|c|c|c|c|c|}
\hline \multirow{2}{*}{ Parameter } & \multirow{2}{*}{ unit } & \multicolumn{4}{|c|}{ Wet Season } & \multicolumn{4}{|c|}{ Dry Season } & \multirow{2}{*}{ WHO Range } \\
\hline & & $\operatorname{Max}$ & Min & Mean & SD & $\operatorname{Max}$ & Min & Mean & SD & \\
\hline $\mathrm{pH}$ & & 6.6 & 5.5 & 6.05 & 0.78 & 6.3 & 5.9 & 6.10 & 0.28 & $6.5-8.5$ \\
\hline $\mathrm{EC}$ & $\mu \mathrm{S} / \mathrm{cm}$ & 0.04 & 0.06 & 0.05 & 0.01 & 0.01 & 0.02 & 0.02 & 0.01 & 1500 \\
\hline Turbidity & NTU & 2.5 & 0.9 & 1.70 & 1.13 & 0 & 0 & 0.00 & 0.00 & 5 \\
\hline $\mathrm{Ca}^{2+}$ & $\mathrm{mg} / \mathrm{L}$ & 0.42 & 0.03 & 0.23 & 0.28 & 4 & 0.3 & 2.15 & 2.62 & 75 \\
\hline $\mathrm{Mg}^{2+}$ & $\mathrm{mg} / \mathrm{L}$ & 0.27 & 0.01 & 0.14 & 0.18 & 0.83 & 0.01 & 0.42 & 0.58 & 125 \\
\hline $\mathrm{K}^{+}$ & $\mathrm{mg} / \mathrm{L}$ & 3.24 & 0.1 & 1.67 & 2.22 & 1.46 & 0.01 & 0.74 & 1.03 & 12 \\
\hline $\mathrm{Na}^{+}$ & $\mathrm{mg} / \mathrm{L}$ & 0.1 & 0.01 & 0.06 & 0.06 & 0.3 & 0.03 & 0.17 & 0.19 & 200 \\
\hline $\mathrm{HCO}_{3}^{-}$ & $\mathrm{mg} / \mathrm{L}$ & 24.4 & 12.2 & 18.30 & 8.63 & 24.4 & 0.4 & 12.40 & 16.97 & $125-130$ \\
\hline $\mathrm{SO}_{4}^{2-}$ & $\mathrm{mg} / \mathrm{L}$ & 0 & 0 & 0.00 & 0.00 & 0.01 & 0.01 & 0.01 & 0.00 & 250 \\
\hline $\mathrm{Cl}^{-}$ & $\mathrm{mg} / \mathrm{L}$ & 7.1 & 2.41 & 7.10 & 0.00 & 3.55 & 2.15 & 3.55 & 0.00 & 250 \\
\hline $\mathrm{Fe}^{2+}$ & $\mathrm{mg} / \mathrm{L}$ & 0 & 0 & 0.00 & 0.00 & 0 & 0 & 0.00 & 0.00 & 0.3 \\
\hline $\mathrm{CO}_{3}^{2-}$ & $\mathrm{mg} / \mathrm{L}$ & 0 & 0 & 0.00 & 0.00 & 0 & 0 & 0.00 & 0.00 & \\
\hline
\end{tabular}

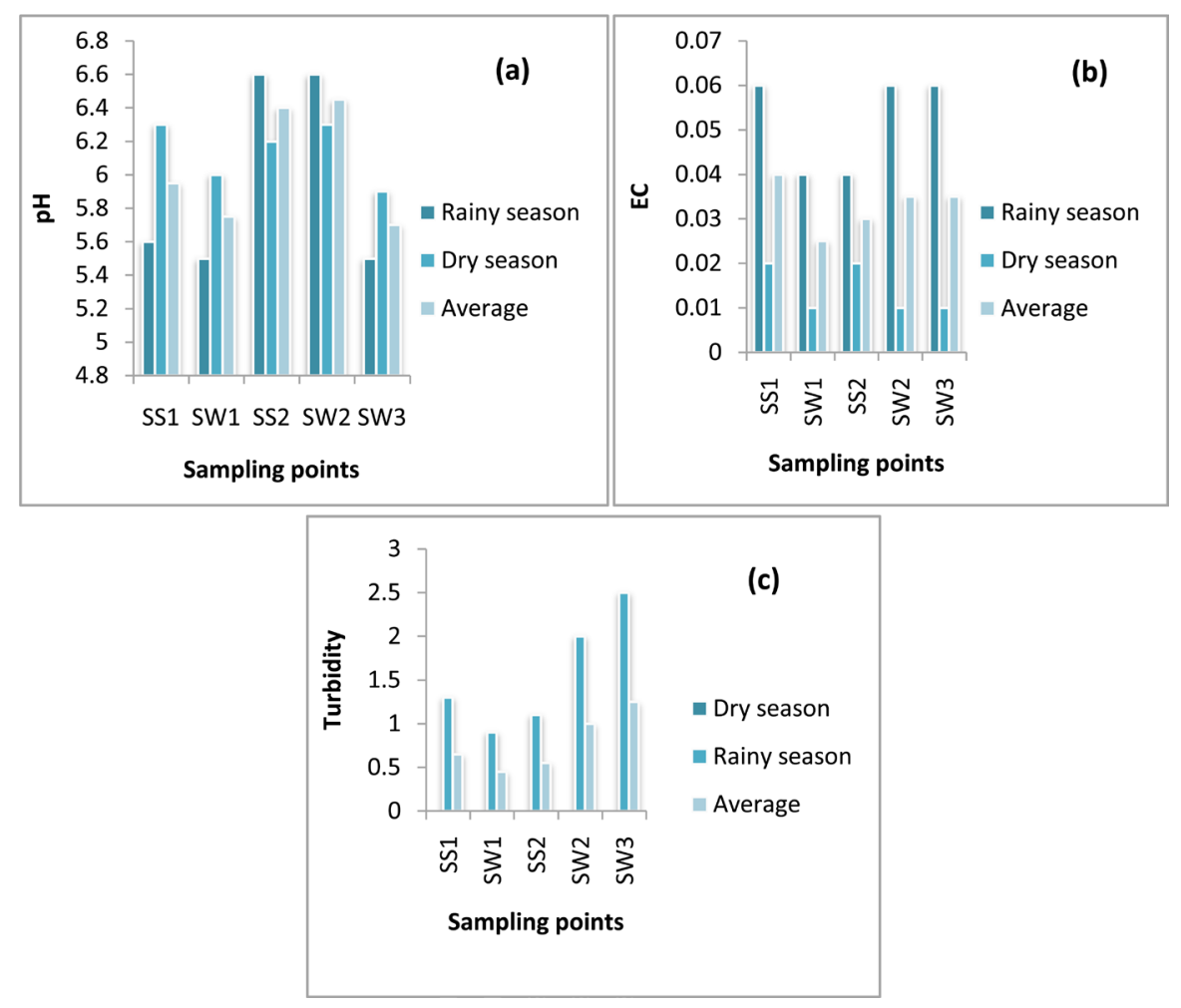

Figure 2. Seasonal variation of physical parameters; (a) $\mathrm{pH}$, (b) Electrical conductivity, (c) Turbidity.

moderately acidic $\mathrm{pH}$ values have been reported by [36] in Ndop plain and [24] in Bamenda III. Water $\mathrm{pH}$ affects most biochemical processes in water such as enzyme activity and solubilisation and uptake of certain ions such as ammonia 
and also limits biodiversity distribution in aquatic habitats [37]. Electrical conductivity values were generally low during the study period and varied from 0.04 $\mu \mathrm{S} / \mathrm{cm}$ to $0.06 \mu \mathrm{S} / \mathrm{cm}$ with an average of $0.05 \mu \mathrm{S} / \mathrm{cm}$ in the wet season while in the dry season, EC ranged from $0.01 \mu \mathrm{S} / \mathrm{cm}$ to $0.02 \mu \mathrm{S} / \mathrm{cm}$ with an average of $0.02 \mu \mathrm{S} / \mathrm{cm}$. The highest value was recorded at WS2 $(0.06 \mu \mathrm{S} / \mathrm{cm})$ and lowest value of $0.01 \mu \mathrm{S} / \mathrm{cm}$ was recorded at WS1 (Table 2), WS2 and WS3 (Figure 2(b)). All EC values were by far below the WHO [35] permissible limits of 1400 $\mu \mathrm{S} / \mathrm{cm}$. The low EC values suggest the occurrence of low mineralized water with very little dissolved solids [2]. The low values of EC are similar to those obtained by [38]. Turbidity values varied from 0.9 NTU to $2.5 \mathrm{NTU}$ with an average of 1.70 NTU in the wet season and no value was detected during the dry period. The highest value was obtained at WS3 (2.5 NTU) and lowest at WS1 (0.9 NTU) in the rainy season. The turbidity values are within the acceptable limits recommended by WHO [35].

The correlation matrix (Table 3 ) shows the relationships between the various physico-chemical parameters of the studied groundwater. It revealed that correlations are not always positive, implying that the variables evolve in different directions, some being very strong (0.937 and 0.88), others median (0.55) and some others quite weak (0.114 and 0.001$)$. EC strongly positively correlated for turbidity and weakly negatively correlated for $\mathrm{Mg}^{2+}$ and $\mathrm{SO}_{4}^{2-}$ while $\mathrm{NO}_{3}^{-}$was strongly positively correlated for $\mathrm{Cl}^{-}$.

\subsection{Chemical Characteristics}

\subsubsection{Cations}

The cations were detected in small concentrations during the study period. The concentrations of $\mathrm{Ca}^{2+}$ and $\mathrm{Mg}^{2+}$ were slightly higher in the dry season than in

Table 3. Correlation matrix (Pearson): Physico-chemical characteristics for dry and wet seasons

\begin{tabular}{|c|c|c|c|c|c|c|c|c|c|c|c|}
\hline Variables & $\mathrm{pH}$ & $\mathrm{EC}$ & Turbidity & $\begin{array}{l}\mathrm{HCO}_{3}^{-} \\
(\mathrm{mg} / \mathrm{l})\end{array}$ & $\begin{array}{c}\mathrm{NO}_{3}^{-} \\
(\mathrm{mg} / \mathrm{l})\end{array}$ & $\mathrm{Ca}^{2+}(\mathrm{mg} / \mathrm{l})$ & $\begin{array}{l}\mathrm{Mg}^{2+} \\
(\mathrm{mg} / \mathrm{l})\end{array}$ & $\mathrm{K}^{+}(\mathrm{mg} / \mathrm{l})$ & $\begin{array}{c}\mathrm{Na}^{+} \\
(\mathrm{mg} / \mathrm{l})\end{array}$ & $\begin{array}{l}\mathrm{SO}_{4}^{2-} \\
(\mathrm{mg} / \mathrm{l})\end{array}$ & $\begin{array}{c}\mathrm{Cl}^{-} \\
(\mathrm{mg} / \mathrm{l})\end{array}$ \\
\hline $\mathrm{pH}$ & 1 & -0.226 & -0.212 & 0.391 & -0.460 & 0.227 & 0.022 & -0.266 & 0.166 & 0.226 & -0.528 \\
\hline $\mathrm{EC}$ & -0.226 & 1 & 0.937 & 0.001 & 0.114 & -0.493 & -0.791 & 0.339 & -0.100 & -0.926 & 0.232 \\
\hline Turbidity & -0.212 & 0.937 & 1 & -0.074 & 0.045 & -0.490 & -0.701 & 0.132 & -0.106 & -0.879 & 0.311 \\
\hline $\mathrm{HCO}_{3}^{-} \quad(\mathrm{mg} / \mathrm{l})$ & 0.391 & 0.001 & -0.074 & 1 & -0.215 & 0.487 & 0.135 & 0.154 & 0.032 & 0.150 & -0.245 \\
\hline $\mathrm{NO}_{3}^{-} \quad(\mathrm{mg} / \mathrm{l})$ & -0.460 & 0.114 & 0.045 & -0.215 & 1 & -0.126 & -0.073 & -0.041 & -0.174 & -0.333 & 0.880 \\
\hline $\mathrm{Ca}^{2+}(\mathrm{mg} / \mathrm{l})$ & 0.227 & -0.493 & -0.490 & 0.487 & -0.126 & 1 & 0.723 & 0.027 & -0.169 & 0.550 & -0.205 \\
\hline $\mathrm{Mg}^{2+}(\mathrm{mg} / \mathrm{l})$ & 0.022 & -0.791 & -0.701 & 0.135 & -0.073 & 0.723 & 1 & -0.194 & -0.377 & 0.760 & -0.086 \\
\hline $\mathrm{K}^{+}(\mathrm{mg} / \mathrm{l})$ & -0.266 & 0.339 & 0.132 & 0.154 & -0.041 & 0.027 & -0.194 & 1 & -0.316 & -0.307 & -0.153 \\
\hline $\mathrm{Na}^{+}(\mathrm{mg} / \mathrm{l})$ & 0.166 & -0.100 & -0.106 & 0.032 & -0.174 & -0.169 & -0.377 & -0.316 & 1 & 0.255 & -0.261 \\
\hline $\mathrm{SO}_{4}^{2-} \quad(\mathrm{mg} / \mathrm{l})$ & 0.226 & -0.926 & -0.879 & 0.150 & -0.333 & 0.550 & 0.760 & -0.307 & 0.255 & 1 & -0.453 \\
\hline $\mathrm{Cl}^{-}(\mathrm{mg} / \mathrm{l})$ & -0.528 & 0.232 & 0.311 & -0.245 & 0.880 & -0.205 & -0.086 & -0.153 & -0.261 & -0.453 & 1 \\
\hline
\end{tabular}


the rainy season but for WS1 which showed a slight decrease during the dry season. Values of $\mathrm{Ca}^{2+}$ ranged from $4 \mathrm{mg} / \mathrm{l}$ to $0.3 \mathrm{mg} / \mathrm{l}$ with a mean of $2.62 \mathrm{mg} / \mathrm{l}$ in the dry season and from $0.42 \mathrm{mg} / \mathrm{l}$ to $0.03 \mathrm{mg} / \mathrm{l}$ with a mean of $0.23 \mathrm{mg} / \mathrm{l}$ in the rainy season. The highest value of calcium was recorded at SS2 and WS2 (4 $\mathrm{mg} / \mathrm{l})$ and the lowest at SS2 $(0.03 \mathrm{mg} / \mathrm{l}) . \mathrm{Mg}^{2+}$ varied from $0.83 \mathrm{mg} / \mathrm{l}$ to $0.01 \mathrm{mg} / \mathrm{l}$ with a mean of $0.42 \mathrm{mg} / \mathrm{l}$ in the dry season and from $0.27 \mathrm{mg} / \mathrm{l}$ to $0.01 \mathrm{mg} / \mathrm{l}$ with a mean of $0.18 \mathrm{mg} / \mathrm{l}$ in the wet season. Highest average value of $\mathrm{Mg}^{2+}$ was recorded at WS1 $(0.83 \mathrm{mg} / \mathrm{l})$ and lowest at SS1 $(0.01 \mathrm{mg} / \mathrm{l})$ as seen in Figure 3(b). $\mathrm{K}^{+}$was higher in the wet season than the dry season but for WS2. $\mathrm{K}^{+}$concentrations ranged from $3.24 \mathrm{mg} / \mathrm{l}$ to $0.1 \mathrm{mg} / \mathrm{l}$ with a mean of $1.67 \mathrm{mg} / \mathrm{l}$ in the rainy season and from $1.46 \mathrm{mg} / \mathrm{l}$ to $0.01 \mathrm{mg} / \mathrm{l}$ with a mean of $0.74 \mathrm{mg} / \mathrm{l}$ in the dry season. The highest value was recorded at SS1 and the lowest at WS1 and SS2 (Figure $3(\mathrm{c})$ ). $\mathrm{Na}^{+}$concentrations varied from $0.3 \mathrm{mg} / \mathrm{l}$ to $0.03 \mathrm{mg} / \mathrm{l}$ with a mean of $0.17 \mathrm{mg} / \mathrm{l}$ in the dry season and from $0.1 \mathrm{mg} / \mathrm{l}$ to $0.01 \mathrm{mg} / \mathrm{l}$ with a mean of $0.06 \mathrm{mg} / \mathrm{l}$ in the wet season.

\subsubsection{Anions}

The bicarbonate ion $\left(\mathrm{HCO}_{3}^{-}\right.$) varied from $24.2 \mathrm{mg} / \mathrm{l}$ to $12.2 \mathrm{mg} / \mathrm{l}$ with a mean of $18.3 \mathrm{mg} / \mathrm{l}$ in the wet season and from $24.4 \mathrm{mg} / \mathrm{l}$ to $0.4 \mathrm{mg} / \mathrm{l}$ with a mean of 12.4 $\mathrm{mg} / \mathrm{l}$ in the dry season (Figure 4(a)). The $\mathrm{HCO}_{3}^{-}$ion is derived partly from the atmosphere, oxidation of organic matter and respiration of plants and soil organisms in the ground water system [39]. Nitrate ion $\left(\mathrm{NO}_{3}^{-}\right)$was detected

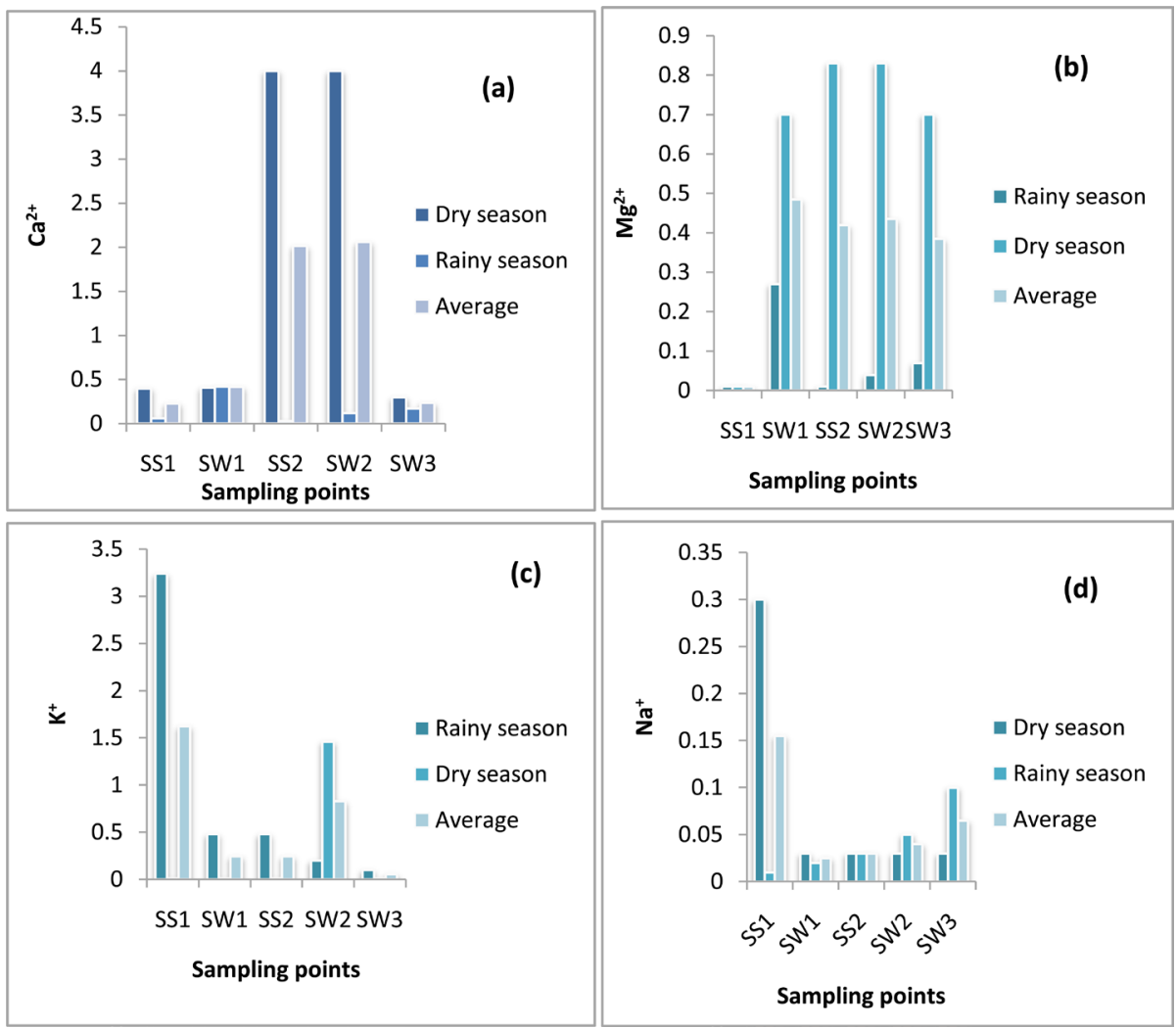

Figure 3. Seasonal variation of major cations: (a) $\mathrm{Ca}^{2+}$, (b) $\mathrm{Mg}^{2+}$, (c) $\mathrm{K}^{+}$, (d) $\mathrm{Na}^{+}$. 
only at one sampling point; WS1 $(3.72 \mathrm{mg} / \mathrm{l})$ during the rainy season (Figure 4(b)). This might have resulted from the decay of vegetation, application of chemical fertilizers, animal feedlots, domestic waste water and the oxidation of nitrogen compounds. The chloride ion $\left(\mathrm{Cl}^{-}\right)$was higher in the rainy season than in the dry season and varied from $7.1 \mathrm{mg} / \mathrm{l}$ to $2.41 \mathrm{mg} / \mathrm{l}$ with a mean of 4.76 $\mathrm{mg} / \mathrm{l}$. In the dry season, it ranged from $3.55 \mathrm{mg} / \mathrm{l}$ to $2.15 \mathrm{mg} / \mathrm{l}$ with a mean of $2.85 \mathrm{mg} / \mathrm{l}^{-\mathrm{Cl}^{-}}$concentration was low in the studied groundwater and was within the WHO acceptable limits. $\mathrm{Cl}^{-}$ion could probably originate from anthropogenic sources or the process of chlorination. Similarly, low values of the $\mathrm{Cl}^{-}$ion have equally been obtained by [40] in Dschang.

Sulphate ion $\left(\mathrm{SO}_{4}^{2-}\right)$ was not detected in the rainy season while in the dry season $0.01 \mathrm{mg} / \mathrm{l}$ was recorded at the SS1 and SW2 sampling points. Iron, phosphates and carbonates were not detected in the studied groundwater samples during the study period.

\subsubsection{Mechanisms Controlling Hydrochemistry}

Gibbs diagrams [41] can provide information on the relative importance of three major natural mechanisms that control water chemistry. These include atmospheric precipitation, mineral weathering and evaporation and fractional crystallization.

The Gibbs diagram for the studied groundwater samples (Figure 5(a) and Figure 5(b)) indicated that water-rock interaction is the dominant process
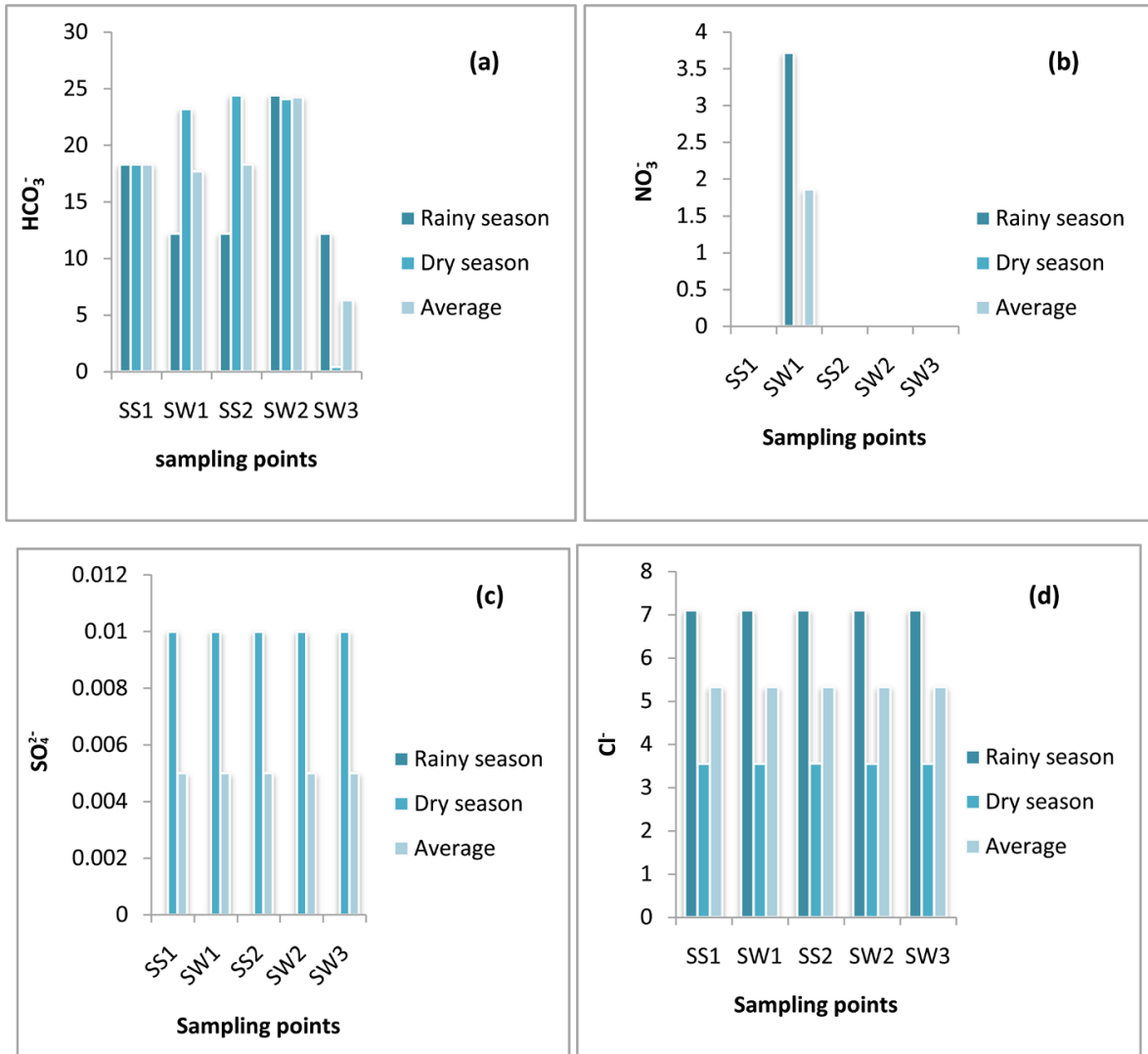

Figure 4. Seasonal variation of anions (a) $\mathrm{HCO}_{3}^{-}$, (b) $\mathrm{NO}_{3}^{-}$, (c) $\mathrm{SO}_{4}^{2-}$, (d) $\mathrm{Cl}^{-}$. 

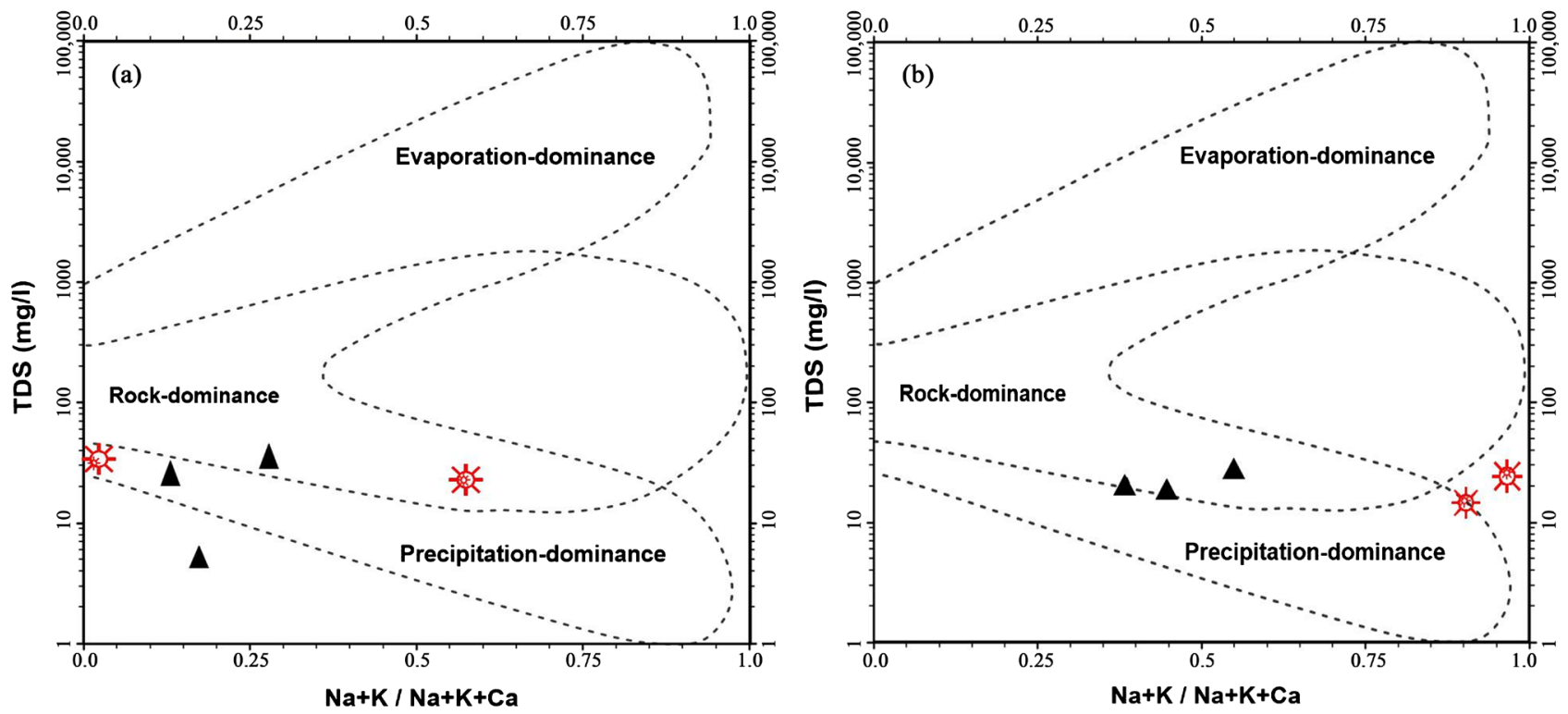

Figure 5. Gibbs plots indicating the main processes controlling the chemistry of groundwater in the study area. (a) Dry season; (b) Rainy season.

controlling the chemical composition of groundwater. In the Dry season, two (02) samples plotted in the rock weathering field, two (02) in the atmospheric precipitation field and 01 sample fell outside the delineated fields. In the rainy season, three (03) samples fell in the rock weathering field, one (01) in the precipitation field and one (01) outside the designated fields. The water sample that plotted outside the three fields may be indicative of anthropogenic influence in altering the chemistry of groundwater. The effect of evaporation on water chemistry was not noticed during the study period as no water sample plotted in the evaporation dominant field. Thus, the weathering of minerals in the host rocks plays a primordial role in controlling the major ion chemistry of groundwater during the study period.

\subsubsection{Water Types}

The Piper diagram (Figure 6(a) and Figure 6(b)) provides information on the different chemical facies present in the studied groundwater samples.

In the rainy season, WS2 and WS1 presented $\mathrm{Na}+\mathrm{K}+\mathrm{NO}_{3}$ facies while SS1, SS2 and WS3 presented the $\mathrm{Ca}+\mathrm{Mg}+\mathrm{NO}_{3}$ facies. In the dry season, all sampling points had the $\mathrm{Ca}+\mathrm{Mg}+\mathrm{NO}_{3}$ facies. This indicates a change in chemical facies with season in some samples. This difference may be due to the hydrogeochemical processes taking place within the aquifer system. The results corroborate with those obtained by [24] in Bamenda III.

\subsection{Bacteriological Characteristics}

Indicator bacteria were detected in all the water samples during the study period with the exemption of Shigella that was absent in WS3 in the rainy season and Vibrio which was completely absent in all the water samples in the dry season. 

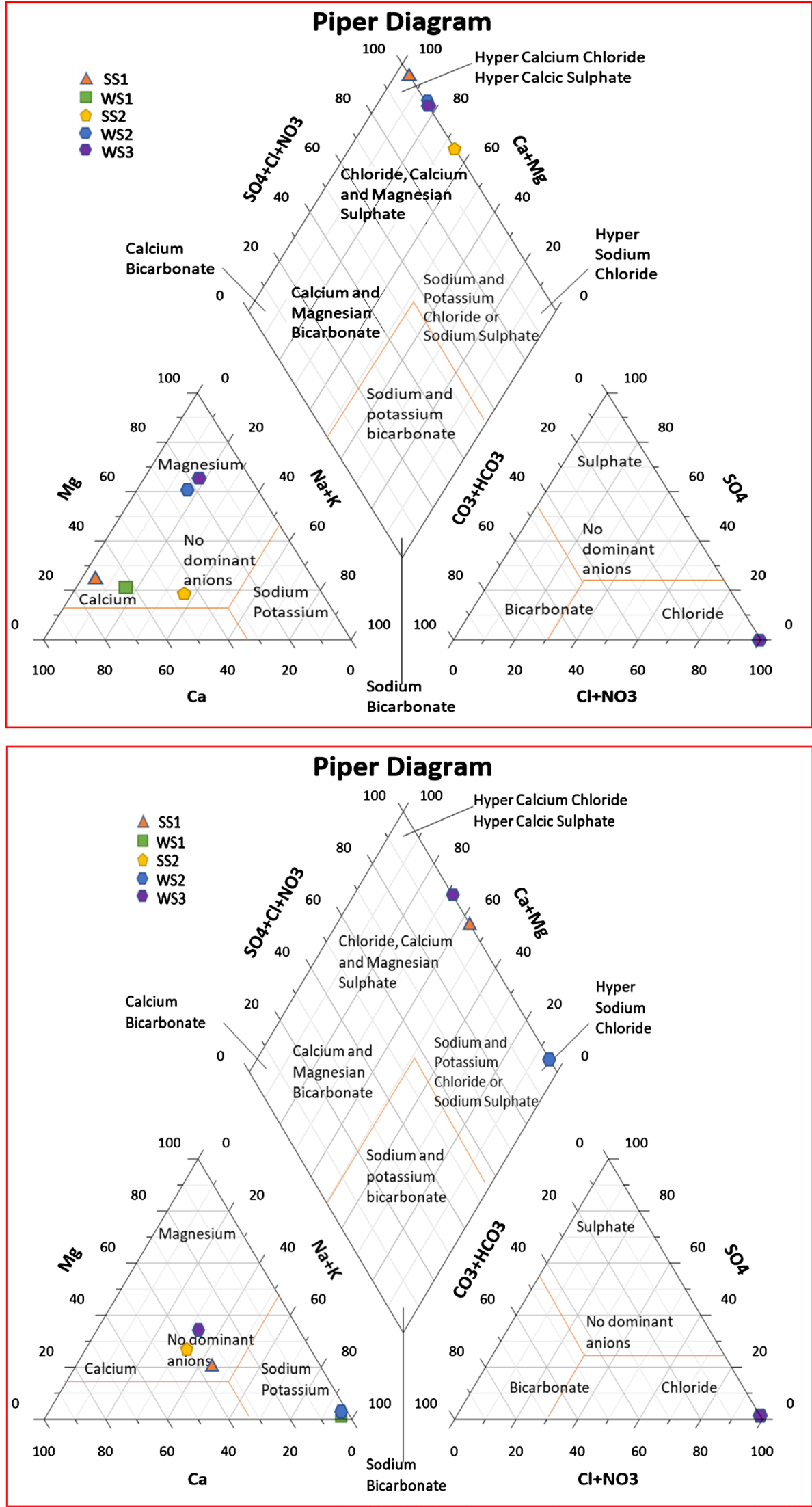

Figure 6. Piper's diagram showing the water types in Bamenda. 
Higher contents were recorded in the rainy season relative to the dry season (Table 4(a) and Table 4(b)). The most recurrent indicator bacteria were Enterobacteria that ranged from $800 \mathrm{CFU} / 100 \mathrm{ml}$ to $450 \mathrm{CFU} / 100 \mathrm{ml}$ with an average of $610 \mathrm{CFU} / 100 \mathrm{ml}$ in the rainy season and from $25 \mathrm{CFU} / 100 \mathrm{ml}$ to 00 $\mathrm{CFU} / 100 \mathrm{ml}$ with an average of $12.4 \mathrm{CFU} / 100 \mathrm{ml}$ in the dry season. E. coli was the second most abundant species and varied from $500 \mathrm{CFU} / 100 \mathrm{ml}$ to 300 $\mathrm{CFU} / 100 \mathrm{ml}$ with an average of $400 \mathrm{CFU} / 100 \mathrm{ml}$ in the rainy season while in the dry season, it ranged from $10 \mathrm{CFU} / 100 \mathrm{ml}$ to $00 \mathrm{CFU} / 100 \mathrm{ml}$ with an average of 5 $\mathrm{CFU} / 100 \mathrm{ml}$. Streptococcus varied from $450 \mathrm{CFU} / 100 \mathrm{ml}$ to $150 \mathrm{CFU} / 100 \mathrm{ml}$ with a mean of $262 \mathrm{CFU} / 100 \mathrm{ml}$ in the rainy season and from $20 \mathrm{CFU} / 100 \mathrm{ml}$ to 00 $\mathrm{CFU} / 100 \mathrm{ml}$ in the dry season with a mean of $8.6 \mathrm{CFU} / 100 \mathrm{ml}$. Salmonella ranged from $350 \mathrm{CFU} / 100 \mathrm{ml}$ to $150 \mathrm{CFU} / 100 \mathrm{ml}$ with an average of $290 \mathrm{CFU} / 100 \mathrm{ml}$ in the rainy season and from $16 \mathrm{CFU} / 100 \mathrm{ml}$ to $00 \mathrm{CFU} / 100 \mathrm{ml}$ with a mean of 6.4 $\mathrm{CFU} / 100 \mathrm{ml}$ in the dry season. Shigella ranged from $60 \mathrm{CFU} / 100 \mathrm{ml}$ to 00 $\mathrm{CFU} / 100 \mathrm{ml}$ with a mean of $28 \mathrm{CFU} / 100 \mathrm{ml}$ in the rainy season and from 40 $\mathrm{CFU} / 100 \mathrm{ml}$ to $00 \mathrm{CFU} / 100 \mathrm{ml}$ with a mean of $3.2 \mathrm{CFU} / 100 \mathrm{ml}$ in the dry season. Staphylococcus varied from $100 \mathrm{CFU} / 100 \mathrm{ml}$ to $10 \mathrm{CFU} / 100 \mathrm{ml}$ with a mean of 42 $\mathrm{CFU} / 100 \mathrm{ml}$ in the rainy season and from $30 \mathrm{CFU} / 100 \mathrm{ml}$ to $00 \mathrm{CFU} / 100 \mathrm{ml}$ in the dry season. Vibrio was detected only in the rainy season and varied from 100 $\mathrm{CFU} / 100 \mathrm{ml}$ to $30 \mathrm{CFU} / 100 \mathrm{ml}$ with a mean of $63 \mathrm{CFU} / 100 \mathrm{ml}$. No indicator bacteria were detected at WS2 in the dry season (Table 4(b)).

Table 4. (a) Bacterial counts of specific microbes isolated in springs and wells in the rainy (CFU/100ml); (b) Bacterial counts for specific microbes in the dry season (CFU/100ml).

(a)

\begin{tabular}{cccccccc}
\hline $\begin{array}{c}\text { Sampling } \\
\text { points }\end{array}$ & Enterobacteria & E. coli & Streptococcus & Salmonella & Shigella & Staphylococcus & Vibrio \\
\hline SS1 & 450 & 300 & 210 & 150 & 50 & 50 & 30 \\
WS1 & 500 & 350 & 200 & 300 & 60 & 100 & 60 \\
SS2 & 800 & 500 & 150 & 350 & 20 & 10 & 75 \\
WS2 & 700 & 450 & 300 & 350 & 10 & 20 & 50 \\
WS3 & 600 & 400 & 450 & 300 & 0 & 30 & 100 \\
Mean & 610 & 400 & 262 & 290 & 28 & 42 & 63 \\
\hline
\end{tabular}

(b)

\begin{tabular}{cccccccc}
\hline $\begin{array}{c}\text { Sampling } \\
\text { points }\end{array}$ & Enterobacteria & E. coli & Streptococcus & Salmonella & Shigella & Staphylococcus & Vibrio \\
\hline SS1 & 7 & 1 & 2 & 4 & 0 & 3 & 0 \\
WS1 & 25 & 4 & 14 & 5 & 2 & 6 & 0 \\
SS2 & 20 & 10 & 7 & 16 & 10 & 30 & 0 \\
WS2 & 0 & 0 & 0 & 0 & 0 & 0 & 0 \\
WS3 & 10 & 10 & 20 & 7 & 4 & 0 & 0 \\
Mean & 12.4 & 5 & 8.6 & 6.4 & 3.2 & 7.8 & 0 \\
\hline
\end{tabular}


The results revealed that there was a substantial difference in the seasonality of the water quality. This might possibly be due to runoff from non point sources infiltrating into the shallow groundwater and also because the wells are not protected and during the wet season run off easily flows in to contaminate the wells. The rainy season may therefore constitute a high risk period of water contamination in that any bacteria that had been trapped within the soil particles in the unsaturated zone is activated by the water column and flows to the discharge points (springs and wells that are used for domestic chores) [15]. This would adversely affect the usage of the water for drinking considering the fact that drinking water should be void of coliform bacteria [42].

Table 5 presents a correlation matrix of the relationships between bacteriological parameters of the studied groundwater. Enterobacteria strongly positively correlated for E. coli and Salmonella but strongly negatively correlated for Staphylococcus. E. coli on the other hand, positively correlated for Salmonella and Staphylococcus while Shigella positively correlated for Staphylococcus.

\subsection{Water Quality Management of the Studied Groundwater Sources-Springs and Hand-Dug Wells}

The studied spring sources in the study area are community point sources that have been constructed to serve as drinking water sources to the community. These springs however, are not protected from animals, livestock and wildlife that could pollute the sources. The Parcours Vita spring is situated at a downhill direction to habitation while the Mile 7 spring is found in an agricultural setting without any demarcation for protection and water from both springs is consumed raw, without any form of treatment. The wells on the other hand are privately owned by individuals, which also serve as drinking water sources in their communities. The wells are dug manually without lining for protection and no water quality testing is done to ascertain the quality. In order to treat the well water, the owners usually pour in "Eau de Javel" after an undefined period of time. In constructing the wells, environmental considerations such as location of pit latrines, piggeries, feedlots and agricultural fields where chemical fertilizers are applied are not taken into account.

Table 5. Correlation matrix (Pearson): Bacteriological indicators for dry and wet seasons.

\begin{tabular}{cccccccc}
\hline Variables & Enterobacteria & E. coli & Streptococcus & Salmonella & Shigella & Stapylococcus & Vibrio \\
\hline Enterobacteria & 1 & 0.994 & -0.068 & 0.808 & -0.668 & -0.764 & 0.421 \\
E. coli & 0.994 & 1 & -0.027 & 0.866 & -0.672 & -0.710 & 0.480 \\
Streptococcus & -0.068 & -0.027 & 1 & 0.106 & -0.668 & -0.209 & 0.563 \\
Salmonella & 0.808 & 0.866 & 0.106 & 1 & -0.541 & -0.333 & 0.566 \\
Shigella & -0.668 & -0.672 & -0.668 & -0.541 & 1 & 0.818 & -0.630 \\
Stapylococcus & -0.764 & -0.710 & -0.209 & -0.333 & 0.818 & 1 & -0.261 \\
Vibrio & 0.421 & 0.480 & 0.563 & 0.566 & -0.630 & -0.261 & 1 \\
\hline
\end{tabular}




\subsection{Suitability of the Studied Spring and Well Water for Water Supply}

Drinking water requires the highest quality standards and therefore continuous monitoring of drinking water sources is imperative to safeguard public health. According to [35] norms for potable water, the $\mathrm{pH}$ values of $90 \%$ of the groundwater samples are below the standards (6.5 - 8.5). Thus, the studied groundwater is weakly acidic and below the permissible limits for consumption, with the exception of SS2 and WS2 which fell within this range during the rainy season sampling campaign. The EC and turbidity of the studied groundwater were below the WHO limits for drinking water. The ionic contents of the studied water sources were equally low and therefore will not pose any health threat to humans who use the sources.

Water hardness is caused by dissolved $\mathrm{Mg}^{2+}$ and $\mathrm{Ca}^{2+}$ ions when it comes in contact with rocks that contain calcium and magnesium. Though hardness has no adverse effect on human health, there is mainly an aesthetic concern because of unpleasant taste that it imparts. On the other hand, soft water with low $\mathrm{Ca}^{2+}$ and $\mathrm{Mg}^{2+}$ contents could be a health problem since soft water has been linked to cardiovascular ailments. The studied groundwater samples are classified as slightly hard water based on a classification scheme by [43] as seen in Table 6.

From a bacteriological standpoint, indicator bacteria were detected at least once in the studied spring and well water samples (Table 4(a) and Table 4(b)) which may endanger the health of the population that use the water for drinking because water intended for drinking should be void of microbes [42].

According to [44] classification of drinking water, the studied groundwater samples can be classified under the following categories in both seasons (Table 7).

\subsection{Suitability for Irrigation}

Plants are sensitive to water quality used for irrigation and the crop yield depends on the type of water used [45]. Irrigation of crops, most especially vegetables, is a common practice in the city of Bamenda during the dry period. This entails assessing the quality of water used as water of poor quality would adversely affect the crops that are irrigated. The quality of water is, thus, an important component with regard to sustainable use of water for irrigated agriculture [46]. The author further notes that high SAR values in the soil from irrigation water leads to a breakdown in the physical structure of the soil, a situation caused by excessive amounts of adsorbed sodium on soil colloids. The classification

Table 6. Water hardness according to [43] classification.

$\begin{array}{cc}\text { Soft water } & 0-17.1 \mathrm{mg} / \mathrm{l} \text { of minerals } \\ \text { Slightly hard water } & 16.1-60 \mathrm{mg} / \mathrm{l} \text { of minerals } \\ \text { Moderately hard water } & 61-120 \mathrm{mg} / \mathrm{l} \mathrm{of} \mathrm{minerals} \\ \text { Hard water } & 121-180 \mathrm{mg} / \mathrm{l} \text { of mineral } \\ \text { Very hard water } & >180 \mathrm{mg} / \mathrm{l} \text { of minerals }\end{array}$


Table 7. Category of groundwater samples during the study period according to [44] classification of drinking water.

\begin{tabular}{ccc}
\hline Sampling points & Seasons & Category \\
\hline SS1 & Rainy & C \\
& Dry & B \\
\hline WS1 & Rainy & D \\
& Dry & D \\
\hline SS2 & Rainy & C \\
& Dry & B \\
\hline WS2 & Rainy & C \\
& Dry & A \\
\hline \multirow{2}{*}{ WS3 } & Rainy & D \\
& Dry & D \\
\hline
\end{tabular}

Table 8. Classification of water sodium hazard based on SAR Values [46].

\begin{tabular}{|c|c|c|c|c|}
\hline \multirow{2}{*}{ SAR values } & \multirow{2}{*}{$\begin{array}{l}\text { Sodium hazard } \\
\text { of water }\end{array}$} & \multicolumn{2}{|c|}{ Water sample } & \multirow[t]{2}{*}{ Comments } \\
\hline & & Wet season & Dry season & \\
\hline $1-9$ & Low & $0.034-0.289$ & $0.193-0.745$ & $\begin{array}{c}\text { Use with caution on sodium } \\
\text { sensitive crops }\end{array}$ \\
\hline $10-17$ & Medium & & & $\begin{array}{l}\text { Amendments (eg gypsum) and } \\
\text { leaching needed }\end{array}$ \\
\hline $18-25$ & High & & & $\begin{array}{l}\text { Generally unsuitable for } \\
\text { continuous use }\end{array}$ \\
\hline$>26$ & Very high & & & Generally unsuitable for use \\
\hline
\end{tabular}

of water sodium hazards based on SAR values shows that all samples were suitable for irrigation (Table 8). Based on this parameter, the studied groundwater samples are suitable for irrigation and do not pose any harmful effect if crops are irrigated with the water as the SAR values of all the water samples during both seasons were low.

\section{Conclusions}

The hydrochemical investigation of groundwater in Northern Bamenda (Cameroon) has contributed to the understanding of groundwater quality in this part of the continental segment of the Cameroon Volcanic Line (CVL). The majority of the physico-chemical parameters were within the WHO acceptable limits, but for a few parameters that did not conform to standard norms. Most of the groundwater samples were weakly acidic, slightly mineralised and slightly hard thus will not impart any adverse effect when used to irrigate crops. Investigating the mechanisms controlling groundwater chemistry using the Gibb's diagram, it was revealed that majority of the groundwater samples plotted in the rock weathering field and a few others in the atmospheric precipitation dominant 
field.

Indicator bacteria were detected in water samples from the springs and hand-dug wells at least once during the study period. The detection of indicator bacteria indicates that the studied groundwater sources are vulnerable to faecal contamination and would require treatment before the spring and well water is used for drinking.

\section{Acknowledgments}

The authors are grateful to anonymous reviewers for their reviews and comments.

\section{Conflicts of Interest}

The authors declare no conflicts of interest regarding the publication of this paper.

\section{References}

[1] Bowers, J. (1997) Sustainability and Environmental Economics. Library of Congress, Singapore.

[2] Falowo, O., Oluwasegunfunmi, V., Akindureni, Y., Olabisi, W. and Aliu, A. (2019) Groundwater Physicochemical Characteristics and Water Quality Index Determination from Selected Water Wells in Akure, Ondo State, Nigeria. American Journal of Water Resources, 7, 76-88.

[3] Shrikant, K., Shridhar, K. and Prajkta, J. (2020) Water Quality Analysis of Urun-Islampur City, Maharashtra, India. Applied Water Science, 10, Article No. 95. https://doi.org/10.1007/s13201-020-1178-3

[4] Owen, L. and Unwin, T. (2002) Environmental Management: Reading and Case Studies. Blackwell, London.

[5] Yildız, D. (2017) The Importance of Water in Development. World Water Diplomacy \& Science News, Hydropolitics Academy, Ankara.

[6] World Bank (2012) Rural Water Supply Design Manual, Water Partnership Program. Volume 1, Phillippines, Minimum Water Quantity Needed for Domestic Uses, WHO Technical Note No. 9, WHO Regional Office for South-East Asia.

[7] WHO/UNICEF (2012) Joint Monitoring Programme for Water Supply and Sanitation Coverage Estimates: Improved Sanitation. Cameroon.

[8] Tirkey, P., Bhattacharya, and Chakraborty, T. (2013) Water Quality Indices-Important Tools for Water Quality Assessment: A Review. International Journal of Advances in Chemistry (IJAC), 1, 1-17.

[9] Sudha, M. (2007) Ground Water Management: Need for Sustainable Approach. Researchgate, 1-10.

[10] Tietenberg, T. (1996) Environmental and Natural Resource Economics. 4th Edition, HarperCollins, Maine.

[11] Akakuru, O.C. and Akudinobi, B.E.B. (2018) Qualitative Characterization of Groundwater Sources around Nigeria National Petroleum Oil Depot Aba, Using Multilinear Regression Modeling. International Journal of Advanced Geosciences, 6, 57-64. https://doi.org/10.14419/ijag.v6i1.8789

[12] Fehdi, C., Boudoukha, A., Rouabhia, A. and Salameh, E. (2009) Caractérisation hydrogéochimique des eaux souterraines du complexe aquifère Morsott-Laouinet 
(Région Nord de Tébessa, Sud-Est Algérien. Afrique Science, 5, 217-231.

[13] Njueya, A.K., Likeng, J.D.H. and Nono, A. (2012) Hydrodynamique et qualité des eaux souterraines dans le bassin sédimentaire de Douala (Cameroun): Cas des aquifères sur formations Quaternaires et Tertiaires. International Journal of Biological and Chemical Sciences, 6, 1874-1894.

https://doi.org/10.4314/ijbcs.v6i4.41

[14] UNICEF (2015) Water a Family Affair: Safe Drinking Water and Sanitation. UNICEF, New York.

[15] Kuitcha, D., Ndjama, J., Tita, A.M., Lienou, G., Kamgang, K.B.V., Ateba, B.H. and Ekodeck, G.E. (2010) Bacterial Contamination of Water Points of the Upper Mfoundi Watershed, Yaounde, Cameroon. African Journal of Microbiology Research, 4, 568-574.

[16] Chatterjee, A.K. (2010) Water Supply, Waste Disposal and Environmental Engineering. 8th Edition, Khanna Publishers, New Delhi.

[17] INS (2008) Annuaire Statistique du Cameroun. Institut National de Statistique, Yaounde.

[18] Mafany, G.T. and Fantong, W.Y. (2006) Groundwater Quality in Cameroon and Its Vulnerability to Pollution. Balkema, Rotterdam, 47-55.

[19] Kamgang, P., Chazot, G., Njonfang, E. and Tchoua, F.M. (2008) Geochemistry and Geochronology of Mafic Rocks from Bamenda Mountains (Cameroon): Source Composition and Crustal Contamination along the Cameroon Volcanic Line. Comptes Rendus Geoscience, 340, 850-857. https://doi.org/10.1016/j.crte.2008.08.008

[20] Gountie, D.M., Nono, A., Njonfang, E., Kamgang, P., Zangmo, T.G., Kagou, D.A. and Nkouathio, D.G. (2009) Le volcanisme ignibritique des monts Bambouto et Bamenda (ligne du Cameroun, Afrique Centrale): Signification dans la formation des caldeiras. Bulletin de I'institut scientifique, 33, 1-15.

[21] Gountié, D.M., Nédélec, A., Nono, A., Njanko, T., Font, E., Kamgang, P., Njonfang, E. and Launeau, P. (2011) Magnetic Fabrics of the Miocene Ignimbrites from WestCameroon: Implications for Pyroclastic Flow Source and Sedimentation. Journal of Volcanology and Geothermal Research, 203, 113-132. https://doi.org/10.1016/j.jvolgeores.2011.04.012

[22] Nono, G.D.K., Wotchoko, P., Magha, A., Ganno, S., Njoya, N., Ngambu, A.A., J.P.Nzenti J and Kabeyene, V.K. (2018) Contrasting Ba-Sr Granitoids from Bamenda Area, NW Cameroon: Sources Characteristics and Implications for the Evolution of the Pan African Fold Belt. Journal of Geosciences and Geomatics, 6, 65-76. https://doi.org/10.12691/jgg-6-2-4

[23] Tita, M.A., Magha, A.M. and Kamgang, K.V. (2013) Microbial Pollution of the Mezam River System and Its Health Impact in Bamenda (North West of Cameroon). African Journal of Microbiology Research, 7, 4940-4948. https://doi.org/10.5897/AJMR2013.5833

[24] Magha, A.M., Tita, M.A., Kouankap, N.G.D., Wotchoko, P., Ayuk, M.T. and Kamgang, V.K. (2015) Physico Chemical and Bacteriological Characterization of Spring and Well Water in Bameneda III (North West Region Cameroon). American Journal of Environmental Protection, 10, 9-11.

[25] Guedjeo, C.S., Kagou, D.A., Ngapgue, F., Nkouathio, D.G., Zangmo, T.G., Gountié, D.M. and Nono, A. (2012) Natural Hazards along the Bamenda Escarpment and Its Environs: The Case of Landslide, Rock Fall and Flood Risks (Cameroon Volcanic Line, North-West Region). Global Advanced Research Journal of Geology \& Mining 
Research, 2, 15-26.

[26] Nfor, J., Azinwi Tamfuh, T.P., Magha, A., Guedjeo, C.S., Tangan, P.A., Nfor, B. and Bitom, D. (2019) Assessment of Community's Perception of Flood Disasters in the Bamenda Municipality, North-West Cameroon. South Asian Journal of Development Research, 1, 9-23.

[27] Ndenecho, E. and Eze, E.B. (2004) Geomorphic and Anthropogenic Factors Influencing Landslides in the Bamenda Highlands, N.W Province, Cameroo. Journal of Applied Social Sciences, 1, 15-26.

[28] Chi, A. (1998) Human Interference and Environmental Instability Addressing the Environmental Consequences of Rapid Urban Growth in Bamenda, Cameroon. Environment and Urbanization, 10, 161-174.

[29] Kometa, S.S. (2013) Wetland Exploitation along the Bafoussam-Bamenda Road Axis of the Western Highlands of Cameroon. Journal of Human Ecology, 41, 25-32. https://doi.org/10.1080/09709274.2013.11906550

[30] Kamgang, P., Njonfang, E., Chazot, G. and Tchoua, F.M. (2007) Géochimie et géochronologie des laves felsiques des Mounts Bamenda (ligne volcanique du Cameroun). Comptes Rendus Géoscience, 339, 659-666.

https://doi.org/10.1016/j.crte.2007.07.011

[31] Tsafack, J.P.F., Wandji, P., Bardintziff, J.M., Bellon, H. and Guillon, H. (2009) The Mount Cameroon Strato Volcano (Cameroon Volcanic Line). Petrology, Geochemistry, Isotope and Age Data.

[32] Kamgang, P., Chazot, G., Njonfang, E., Tchuimegnie, N. and Tchoua, F. (2013) Mantle Sources and Magma Evolution beneath the Cameroon Volcanic Line: Geochemistry of Mafic Rocks from the Bamenda Mountains (NW Cameroon). Gondwana Research, 24, 727-741. https://doi.org/10.1016/j.gr.2012.11.009

[33] Nzenti, J.P., Abaga, B., Suh, C.E. and Nzolang, C. (2010) Petrogenesis of Peraluminous Magmas from the Akum-Bamenda Massif, Pan-African Fold Belt, Cameroon. International Geology Review, 53, 1121-1149. https://doi.org/10.1080/00206810903442402

[34] APHA (American Public Health Association) (1985) Standard Methods for the Examination of Water and Wastewater. APHA, Washington DC.

[35] World Health Organization (WHO) (2006) Guidelines for Drinking Water Quality. Vol. 1, 3rd Edition, WHO, Geneva.

[36] Wirmvem, M.J., Takeshi, O., Fantong, W.Y., Ayonghe, S.N., Suila, J.Y., Asobo, N.E., Tanyileke, G. and Hell, J.V. (2013) Hydrochemistry of Shallow Groundwater and Surface Water in the Ndop Plain, North West Cameroon. African Journal of Environmental Protection and Technology, 7, 518-530. https://doi.org/10.5897/AJEST2013.1456

[37] Dirisu, C.G., Mafiana, M.O., Dirisu, G.B. and Modou, A.R. (2019) Level of pH in Drinking Water of an Oil and Gas Producing Community and Perceived Biological and Health Implications. European Journal of Basic and Applied Sciences, 3, 2059-3058.

[38] Alakeh, N.M., Njoyim, E.B.T. and Mvondo-Ze, A.D. (2017) Quality Assessment of Some Springs in the Awing Community, North West Cameroon and Their Health Implications. Journal of Chemistry, 2017, Article ID: 3546163. https://doi.org/10.1155/2017/3546163

[39] Zheng, X.D., Zhang, H.Y. and Xi, Y.F. (2004) Effects of Cryptococcus laurentii (Kufferath) Skinner on Biocontrol of Postharvest Decay of Arbutus Berries. Botanical Bulletin-Academia Sinica, 45, 55-60. 
[40] Temgoua, E. (2011) Chemical and Bacteriological Analysis of Drinking Water from Alternative Sources in the Dschang Municipality, Cameroon. Journal of Environmental Protection, 2, 620-628. https://doi.org/10.4236/jep.2011.25071

[41] Gibbs, R.J. (1990) Mechanisms Controlling World's Water Chemistry. Science, 170, 1088-1090. https://doi.org/10.1126/science.170.3962.1088

[42] IRC (International Reference Center for Community Water Supply and Sanitation) (1983) Small Community Water Supplies. John Wiley and Sons, Technical Paper Series, No. 28, Netherlands.

[43] Todd, D.K. (1980) Groundwater Hydrology. 2nd Edition, Wiley, New York.

[44] Cheesbrough, M. (1991) Medical Laboratory Manual for Tropical Countries. Low Priced Edition, Daddington, Cambridgshire.

[45] Shashank, S. (2017) Assessment of Groundwater Quality. ResearchGate, Delhi, 1-19.

[46] Mohammad, Z., Shabbir, A. and Lee, H. (2018) Irrigation Water Quality. International Atomic Energy Agency, Vienna. 